\title{
Arte e informação:o papel das redes de informação na comercialização, divulgação e realização da arte contemporânea
}

\author{
Rubens Estevão Costa de Morais Querino
}

Especialista em Gestão Estratégica da Informação pela Escola de Ciência da Informação da UFMG.Bacharel em Artes Visuais pela Escola de Belas Artes da UFMG.

Marta Araujo Tavares Ferreira

Doutora pela Ecole Centrale de Paris. Pós Doutoramento na Université de Montreal. Professora da Escola de Ciência da Informação da UFMG

http://dx.doi.org/10.1590/1981-5344/2219

"Vincent Van Gogh, o maldito, o exilado da sociedade, estabelece o paradigma, obtendo todas as aprovações". (CAUQUELIN, 2005, p. 48).

Dentro do grande tema Arte e Informação, foi pesquisada a importância das novas tecnologias de informação, a internet e as redes sociais, como forma de interação entre os diversos agentes que atuam no sistema de arte, tendo como base o esquema tripartite proposto por Anne Cauquelin, produção, distribuição e consumo. A aproximação interdisciplinar entre essas áreas do conhecimento permite vislumbrar a forma como a arte contemporânea e o artista contemporâneo se inserem neste meio informacional. Vivemos na era da informação, portanto o indivíduo artista está inserido nesse mundo, e precisa conviver com as novas tecnologias da informação. Faz-se necessário um olhar mais atento sobre o comportamento da arte e do artista diante do mundo contemporâneo mergulhado na era da informação extrema, seja como forma de expor trabalhos de arte, propagar ideias ou mesmo como forma de criação artística. Foi surpreendente perceber como essas áreas tão distintas podem se relacionar de forma tão íntima, e como a Ciência da Informação contribui para a formação cultural e construção do conhecimento da sociedade contemporânea. Através de questionário aplicado a 
profissionais da área - artistas de diversas especialidades, críticos, galeristas, etc.- foi possível estabelecer um contato mais próximo sobre o pensamento do próprio indivíduo acerca de sua interação com o mundo da informação, e os benefícios que se pode obter pelo uso da internet e das redes sociais.

Palavras-chave: Arte e informação; Arte e internet; Redes sociais; Arte contemporânea.

\section{Art and information: the role of information networks in themerchantability, dissemination and realization of the contemporary art}

Within the great theme Art and Information, it was researched the importance of the new technologies of information, the internet and social networks, as a way of interaction between the various actors involved in the system of art, based on the tripartite scheme proposed by Anne Cauquelin: production, distribution and consumption. The interdisciplinary approach between these areas of knowledge provides a glimpse of how the contemporary art and the contemporary artist insert themselves into this informational environment. We live in the information age, so the individual artist is inserted in this world, and has to live with the new information technologies. It is necessary a closer look on the behavior of the art and the artist on the contemporary world plunged in the extreme information age, either as a way to exhibit works of art, propagate ideas or even as a form of artistic creation. It was amazing to see how these areas so distinct can relate so intimately, and how information science contributes to cultural and knowledge construction of the contemporary society. Through a questionnaire applied to professionals of the area - artists of various specialties, critics, gallerists, etc. - it was possible to establish a closer contact on the individual's own thinking about their interaction with the world of information, and the benefits that can be obtained by using the internet and social networks. 
Keywords: Art and information; Art and internet; Social networking; Contemporary art.

Recebido em 12.08.2014 Aceito em 22.09.2015

\section{Introdução: Arte e Informação, aproximação pelo conhecimento}

O artista contemporâneo, pós-moderno, o artista visual, o artista plástico, e aqui entram diversas outras terminologias ou mesmo categorias, é também um indivíduo que vive em um mundo contemporâneo, sendo influenciado por ele a todo instante, sofrendo impactos na sua maneira de se relacionar, pensar, agir, etc.; um mundo no qual o conceito de redes já faz parte do imaginário coletivo como uma metáfora de interação social, experiência, produção e consumo, assim como a máquina e as engrenagens o faziam na era industrial; um mundo no qual a oposição entre a individualidade e a coletividade, também se repete historicamente, estando hoje relacionada ao indivíduo e às novas tecnologias da informação. A forma como o indivíduo se agrupa, seja eletronicamente ou não, para formar grupos ou comunidades, ou se isola, mesmo estando conectado à rede, nos revela uma relação esquizofrênica, entre a rede e o ser (CASTELLS, 1999).

É realmente surpreendente a descoberta de como todos os campos de conhecimento se conectam, sistemicamente, e que duas áreas tão distintas - Artes Visuais e Informação - possam se relacionar tão intimamente, convergindo numa forma de entender o mundo, muito característica da atualidade. É quase espantoso, como vai ser demonstrado nos exemplos mais a frente, a forma como a arte se apropria da teoria de sistemas, teoria de redes, conceitos de bancos de dados, tecnologia da informação e até mesmo códigos genéticos, e o que faz a partir da combinação destes elementos, em termos de criação artística. Na verdade, o envolvimento das artes com as tecnologias, assim como a globalização, são ideias muito antigas, que estiveram sempre presentes na história da humanidade. A própria palavra arte já apresenta, em sua origem, a ideia de tecnicidade, de tecnologia. E ainda, o próprio objeto artístico, a obra de arte, já é por si só um mecanismo de diversas interações sociais, um dispositivo que vai muito além de sua presença física, para alcançar as questões de diversas naturezas, em diversos aspectos, atingindo uma virtualidade, tornando- se, como muito bem aponta Gonçalves (2009), um verdadeiro laboratório de experimentações sociais. Chegamos aqui a um ponto importante, que é o ponto de fusão desses conceitos, com o surgimento das novas tecnologias de interação social: o surgimento da internet e das redes sociais, e suas aplicações nas artes visuais.

Na busca pelo melhor entendimento dessas aplicações, é que se desenvolveram as questões pertinentes a que este trabalho busca responder. Fez-se necessário discutir a importância das novas tecnologias, 
como a internet, sobretudo as redes sociais, como catalisadores desta dinâmica, que seria o entendimento do mundo das artes visuais como um sistema, um sistema de redes,onde é necessário entender a importância das relações existentes entre os agentes atuantes nessa teia: artistas, curadores, galeristas, consumidores, produtores.

Para melhor entendimento dessas relações, através de comparações entre os esquemas da arte moderna e contemporânea propostos por Anne Cauquelin (2005), e as teorias de rede, é possível pensar o mundo da arte como um sistema de redes, onde cada agente atuante é um nó, que está ligado a outros inúmeros nós, formando inúmeros universos (seção 2). Portanto, muitas vezes a conexão entre dois universos distintos pode ser feita a partir da simples conexão entre dois nós; estão assim abertas as portas para uma imensidão de novas possibilidades de conexões.

Além de se investigar o uso das redes de informação como estratégia de inserção no mercado (seção 3), buscou-se pesquisar a influência das redes também na forma de criação artística $e$, através de exemplos de artistas que utilizam a internet no processo criativo, foi possível entender que há embutido no próprio conceito de obra de arte, a ideia de rede, de virtualismo, de interação social.

As diferentes atitudes do artista diante da tecnologia da informação, seja como forma de divulgação de obras de arte, seja usando a rede num processo de ativismo, são discutidas na seção 4 e, nas seções 5 e 6, são apresentados o procedimento e os resultados de um levantamento realizado sobre a relação do artista brasileiro com a internet.

\section{Mercados e redes de arte}

"é o conhecimento desse sistema que permite apreender o conteúdo das obras.” (CAUQUELIN, 2005, p. 14).

A figura da rede é a imagem mais utilizada para designar ou qualificar sistemas. Anne Cauquelin (2005) descreve a arte contemporânea como um sistema que se divide em dois esquemas: uma cadeia de consumo linear, ainda resquício da arte moderna; e um esquema circular de comunicação, ligado à arte contemporânea, que se desenvolveu a partir do surgimento de dois grandes ícones emblemáticos: Marcel Duchamp e Andy Wharol. Nesses dois esquemas atuam diversos agentes, distribuídos, de forma geral, nas categorias produtor, mediador e consumidor. O que nos leva a um sistema tripartite: produção, distribuição e consumo, sendo que o que se produz na arte, muito além se caracterizar como bens materiais, são bens simbólicos.

O primeiro esquema se desenvolveu a partir de características herdadas historicamente a partir do rompimento da arte com a academia real, e das transformações sociais que permeavam o mundo, quando as revoluções industriais e o surgimento da arte moderna resultaram em uma quebra de paradigmas de uma arte dita "oficial" e na descentralização do controle do entendimento do que seria "bom" ou "ruim". Daí surgiram os movimentos, onde os artistas se agrupavam em 
grandes galpões para divulgarem seu trabalho, e começou-se um novo mercado, maior e mais abrangente, com novas características.

As exposições acontecem às margens dos locais oficiais: Courbet e Manet têm seu próprio pavilhão na Exposição universal de 1867. Os impressionistas decidem reunir-se na casa de Nadar (1874)), de Durand-Ruel (1876) [....] O dinamismo desloca-se progressivamente na direção do empreendimento privado, das sociedades como a dos aquafortistas (1872) ou das galerias de exposição de marchands como Durand- Ruel. (HARZAN,1990, p.100 citado por CAUQUELIN, 2005, p.36).

A ausência das atividades econômicas das quais a Academia Real havia muito se desobrigado doravante se faria sentir de forma muito cruel. O Hotel Drouot era o único recurso da estrutura acadêmico-governamental que permite vender as obras de arte aos indivíduos. Ademais, a maior parte das vendas por leilão ali organizados era de antigos mestres ou de antiguidades. O sistema acadêmico não soube nem desenvolver nem cultivar os diversos mercados potenciais que existiam dentro de um público aumentado de compradores, assim como também não soube, na mesma proporção, encorajar a identificação das individualidades artísticas com esses mercados. (HARRISON; WHITE, 1965, p.157 citado por CAUQUELIN, 2005, p.35).

Daí surge a especialização dos salões e a descentralização do mercado, ou seja, a abertura de um mercado independente: o sistema marchand-crítico, onde há uma grande elevação da importância das figuras intermediárias como verdadeiros fabricantes da demanda. De um lado tem-se uma circularidade, ou continuidade linear, onde o consumidor participa do processo de produção da demanda, por outro lado os intermediários-marchands exercem uma incitação ao consumo, através da influência que sua opinião propicia.

No espaço altamente segmentado da arte contemporânea, marcado pela pluralidade, um dos maiores constrangimentos com o qual o artista se defronta é a preponderância da mídia. Se, na anomia moderna, os artistas se defrontam com os colecionadores e os marchands, enfim, com o mercado, na entropia contemporânea, o grande desafio é a mídia de massa. Essa uma das principais mudanças que assinalam a passagem do mundo da arte moderna para o mundo da arte contemporânea. A contraposição das trajetórias de Vincent van Gogh, Marcel Duchamp / Jackson Pollock, Andy Warhol, Joseph Beuys / Jean-Michael Basquiat, Julian Schnabel e Jeff 
Koons é ilustrativa em direção da construção do prestígio artístico: da legitimidade adquirida no interior de um mercado associado ao campo artístico à consagração na mídia de massa. (BUENO, 2010, p.44).

Essa liberação da arte moderna em relação ao sistema de arte acadêmico origina-se do liberalismo econômico, do surgimento da burguesia, e da mudança dos valores da sociedade em relação à produção e consumo. Da impotência do sistema acadêmico em gerir o domínio da arte e dos artistas, em franca expansão, surge a palavra de ordem "contra a academia", o que não representava necessariamente uma recusa aos valores do antigo sistema, mas sim uma mudança na forma de distribuição, indo das mãos do Grande Salão às mãos dos marchands, dos críticos e dos compradores. O sucesso representava reconhecimento, confirmação e, portanto dinheiro. Os artistas necessitavam do reconhecimento do talento e da remuneração.

No segundo esquema, o da arte contemporânea, ligada ao regime da comunicação, produtores, intermediários e consumidores não podem mais ser distinguidos. Todos os papéis podem ser desempenhados ao mesmo tempo. O percurso de uma obra até o consumidor presumido não é mais linear, mas circular. Há o abandono dos movimentos de vanguarda e do romantismo da figura do artista. O artista agora é um artista de negócios. É ele que leva adiante sua propagação, sua própria imagem. Nesse modelo, a mensagem da obra de arte se torna mais importante que o objeto, há o abandono da habilidade manual, há a valorização do acaso e da escolha. Os papéis se misturam, sendo que o artista atua como produtor, como marchand. E o sistema da arte nesse esquema é organizado em rede, e já não está em conflito com o sistema geral (social, econômico, político), mas integrado a ele.

[...] Duchamp desmonta a antiga ideologia do artista exilado, recusado, contestador: a estética não é um domínio que tem leis diferentes do sistema geral. É uma simples peça dentro de um jogo de comunicação, cuja entrada, assim como a saída, não pode ser encontrada. Não há origem nem fim, é um círculo. As operações que se desenrolam no interior de uma rede têm a ver com propriedades de rede, não com a vontade do artista. Cada ponto da rede está ligado aos outros, cada interveniente pode estar em toda parte ao mesmo tempo. [...] não existe vanguarda propriamente dita; não existem manifestações anti-sociedade ou anti-marchands. Muito ao contrário, o jogo da arte consiste em especular a respeito do valor da simples exposição de um objeto manufaturado. A exposição, a colocação no circuito por si só institui o valor do signo, valor especulado que pertence de pleno direito, de um direito teoricamente axiomatizado, ao domínio da arte. (CAUQUELIN, 2005, p.99). 
Andy Warhol, assim como Duchamp, renuncia à habilidade manual e à estética do gosto, e colocando em prática seu conhecimento em redes, abandona também esse último refúgio, adotado ainda por Duchamp - o local de exposição- para se estabelecer no espaço inteiro das comunicações, utilizando conceitos que regem a comunicação: a rede, com a redundância e a saturação; o paradoxo, o bloqueio em torno de si mesmo; a autoproclamação com o nominalismo; a circulação dos signos dentro da rede sem autor nem receptor, e finalmente o totalitarismo, com a internacionalização do sistema de comunicação (CAUQUELIN, 2005).

É um sistema como esse, em seu estado contemporâneo, que tentaremos apresentar aqui. 'Estado contemporâneo' significa que esse sistema não é mais o sistema que prevaleceu até recentemente; ele é o produto de uma alteração de estrutura de tal ordem que não se podem mais julgar nem as obras nem a produção delas de acordo com o antigo sistema. É justamente neste ponto que se instala o mal-estar: avaliar a arte segundo critérios em atividade há somente duas décadas é não compreender mais nada do que está acontecendo. (CAUQUELIN, 2005, p.15).

Não está claro, portanto, a distinção do que seria um sistema contemporâneo de arte. Mas o que parece evidente, é que muito deste sistema onde o intermediário ganha demasiada importância, está presente ainda hoje, nas redes sociais da arte contemporânea, sejam elas virtuais ou não, sendo que os dois esquemas apresentados se misturam, o que torna um pouco confuso entender o mercado das artes visuais recente. Essa dificuldade parte às vezes do próprio objeto artístico, como pode ser notado neste trecho:

Em relação às querelas do século passado, a especificidade da situação atual reside o fato de que não existe mais um único mundo da arte (manifestado nos salões de então) nem uma definição do que são ou devem ser as artes plásticas, mas várias. As diferentes maneiras de fazer arte não estão mais dispostas gradativamente num único eixo, entre pólo inferior e superior, mas em vários eixos. Assim, as querelas não dizem mais respeito somente a questões estéticas de avaliação ("É mais ou menos bonito ou bem feito") e de gosto ("Gostamos mais ou menos"), mas a questões ontológicas ou cognitivas de classificação ("É ou não é arte") e de integração ou exclusão ("Aceito ou não aceito tal proposição enquanto obra de arte"). Para tomar um exemplo paradigmático: o problema não é que Duchamp fizesse uma pintura ruim (como foram acusados os impressionistas), mas que o que ele fez não é pintura, nem escultura, embora pretendendo ser arte (HEINICH, 2008, p. 180 citado por BUENO, 2010, p.41). 
Bueno (2010) aponta que há uma expansão do repertório técnico e da base material no ateliê do artista contemporâneo que ampliou as fronteiras das artes plásticas, aproximando-as de outros domínios e linguagens extrapolando o âmbito das artes, enveredando por outros territórios, como o vídeo, a internet, a alta tecnologia de um modo geral. Como por exemplo, no domínio da comunicação, a ambiguidade irônica que existe no processo de venda da imagem do artista enquanto autor e personagem, que é um assuntoabordadocomo foco principal da obra de Warhol,que busca através dos efeitos da mídia na sociedade contemporânea criar em sua própria imagem um personagem como parte de uma estratégia para obter reconhecimento, 0 que acabou desagradando a muitos no campo artístico.Nessa aproximação de outros territórios, a arte também se envereda em causas politizadas, como a defesa da ecologia feita por Beuys.

Joseph Beuys foi outro artista [...] que recorreu à mídia para fazer a crítica da institucionalização da arte e para divulgar sua obra, que colocou a serviço de várias causas, entre as quais, a defesa da ecologia. Uso da mídia de massa, arte a serviço de causas políticas e sociais, autores-personagens, e assim, gradativamente, a autonomia do campo artístico foi ficando cada vez mais comprometida, à medida que a autonomia da arte se revelava como uma impossibilidade na sociedade moderna e que os artistas não tinham interesse em preservá-la. (BUENO, 2010, p.45).

O que se observa aqui é a perda da autonomia da arte, e a falta de interesse em preservar essa autonomia.

\section{Tecnologias da informação, internet e redes sociais nas artes visuais}

Aguiar (2006) aponta que os conceitos básicos e técnicas de análises sobre as redes sociais remontam a estudos realizados entre as décadas de 1930 e 80, bem antes das tecnologias de informação e comunicação assumirem papel significativo na intermediação das relações interpessoais e sociais.

Foram esses estudos que começaram a utilizar as metáforas de "tecido" e "teia" para dar conta das relações de "entrelaçamento" e de "interconexão" através das quais as interações humanas e as ações coletivas são articuladas. Ou seja, muitas ideias e reflexões afloraram antes de o economista Manuel Castells e o físico Fritjof Capra lançarem seus holofotes sobre as redes - um motivado pelo interesse na globalização, e o outro pela filosofia do conhecimento. (AGUIAR, 2006, p.7). 
Recentemente, em outubro de 2012, num ciclo de palestras intitulado Simpósio Internacional Futuros Possíveis, FAU-SP, Patrícia Canetti, do portal artístico Canal Contemporâneo, realizou uma palestra intitulada Análise e Visualização de Eventos de Arte como Rede Social, oferecendo um exemplo ilustrativo sobre comoo portal artístico Canal Contemporâneo, através de seu colecionismo de eventos de arte, se tornou fundamental no processo de construção "artesanal" de uma rede social da arte contemporânea, viva, em constante movimento. Também é mencionada a forma como os padrões de coletividade se somam na formação das individualidades, não por simples adição, mas por interseção e combinação de inúmeras inter-relações e entrelaçamentos, assim como, numa dinâmica inversa, os padrões de individualidade atuam na construção das coletividades.

Para Canetti a ideia de redes e mapeamento está intimamente ligada ao ser humano no nível mais profundo da genética:

O que mais me interessa no Genoma Humano é o fato dele nos evidenciar uma ampla descendência e, a partir dela, podermos entrar em contato com o fato de sermos feitos de pedaços. Pedaços, que nos estruturam e que nos conectam ao exterior e ao coletivo. É a percepção inédita do coletivo em nosso interior, mesclada à vivência de rede das novas tecnologias, que nos possibilitam vislumbrar novas relações entre a individualidade e a coletividade na condição humana. (CANETTI, 2012, p.3).

Assim como nos mostra Castells:

Como tecnologia, entendo, em linha direta com Harvey Brooks e Daniel Bell, "o uso de conhecimentos científicos para especificar as vias de se fazerem as coisas de uma maneira reproduzível". Entre as tecnologias da informação, incluo, como todo o conjunto convergente de tecnologias em microeletrônica, computação (hardware e software), telecomunicações/radiodifusão, e optoeletrônica. Além disso, diferentemente de alguns analistas, também incluo nos domínios da tecnologia da informação a engenharia genética e seu crescente conjunto de desenvolvimentos e aplicações. [...] Assim, computadores, sistemas de comunicação, decodificação e programação genética são todos amplificadores e extensões da mente humana. (CASTELLS, 2002, p.67 e 69).

Canetti (2012), ainda nos leva a refletir sobre as relações entre a arte e as redes sociais:

Para transformarmos a informação de eventos de arte em uma rede social - ou seja, uma estrutura social formada por atores, 
como indivíduos e organismos, e as relações entre eles precisamos de dados detalhados e confiáveis, mas também de uma arquitetura de dados que permita relacionar os atores a partir dos eventos. ATORES=INDIVÍDUOS E ORGANISMOS. As redes complexas são uma descoberta recente para o Canal Contemporâneo, que vem se delineando desde que entramos no ar em dezembro de 2000. [...] Ver o circuito de eventos de arte como uma rede social, aonde os nós, chamados atores, são os integrantes destes eventos - artistas, curadores, museus galerias - e as conexões, chamadas relações, são resultado de suas participações (ou afiliações) aos eventos, é o primeiro passo para que esta nova abordagem levante questões importantes sobre o sistema, o circuito e a história de arte em processo. Seguindo os preceitos de Teoria de Redes, passamos a nos interessar mais pelas relações entre os atores, e os padrões que estas relações formam, do que pelas características específicas dos atores. [...] nosso primeiro exercício [...] para explicitar as configurações do circuito de arte como uma rede e, por consequência, criar dispositivos de leituras para a história da arte como rede social. Este projeto cria um dispositivo de leitura do circuito das artes visuais agregando uma documentação da produção atual, recente, viva, em constante movimento. (CANETTI, 2012, p.4).

Já Gonçalves (2009) nos traz outros exemplos de interação entre Artes Visuais e as redes de Informação. Primeiramente, o uso da tecnologia da informação na arte pode proporcionar espaços de ação coletiva ou de criação colaborativa à distância; como o caso que ficou conhecido como "Toywar" em 1999 - uma disputa judicial entre a loja virtual de brinquedos EToy e o "coletivo" suíço de artistas Etoy pelo direito do uso do domínio www.etoy.com. Tendo perdido judicialmente, o Etoy orquestrou uma série de ações, inclusive, com ajuda de outros grupos artísticos ativistas, de ataques online (hacktivismo) a base de congestionamento de sites através de acessos contínuos, prática também conhecida como bloqueio virtual (virtual sit-in). As ações foram divulgadas em listas de e-mails e de discussão na internet, tendo adesão de centenas de pessoas. Foram 12 dias de bloqueio, que provocaram a queda das ações da EToy, o que levou a empresa a voltar atrás na disputa judicial.

Toywar foi um evento multimídia orquestrado para virar a mesa contra a EToy. Foi pedida a revisão do processo na justiça e feito lobby online com investidores e acionistas da empresa de brinquedos. Press-releases foram enviados à imprensa denunciando o caso como abuso de poder e articulistas foram contatados e escreveram artigos sobre 0 procedimento da EToy. Como se não bastasse, Etoy acionou o ElectronicDisturbanceTheater (EDT) e outros grupos de arte e 
ativismo como RTMark e Thing. Net e juntos promoveram 12 dias de ação online contra o site da EToy às vésperas do Natal. [...] Em 15 de janeiro de 2000, os artistas recebiam de volta seu domínio e mais o pagamento de uma importante multa paga pela EToy [...] (GONÇALVES, 2009, p. 105).

Arte, informação genética, ativismo biopolítico, também andam juntos no trabalho intitulado "Genesis" (1999), do artista brasileiro radicado nos Estados Unidos, Eduardo Kac, no qual foi criado um gene que sofre mutação através de intervenção coletiva pela internet. Kac é comunicólogo de formação, e já trabalhou com poesia holográfica, explorações em robótica e atualmente vem desenvolvendo experimentos genéticos como forma de investigar a condição humana. Segundo o site www.ekac.org, Genesis é uma obra de arte transgênica que explora a intricada relação entre biologia, sistemas de crença, tecnologia da informação, interação dialógica, ética e a internet.

Um ano antes do controverso projeto "GFP Bunny" (2000), onde introduzira em laboratório um gene fluorescente na coelha Alba, que brilhava em tom verde no escuro, Kac havia criado "Genesis" (1999). Nesse projeto, Kac criou um "gene de artista": um gene artificial, não existente na natureza. O artista explica no site do trabalho que o gene foi sintetizado através da tradução de um trecho em inglês do Velho Testamento para código Morse e depois de código Morse para DNA, de acordo com um código desenvolvido por Kac especialmente para esta obra (os traços do código Morse representam a timina, os pontos a citosina, o espaço entre as palavras a adenina e o espaço entre as letras a guanina; assim, têm-se os quatro constituintes fundamentais do DNA, cujas combinações formam o "alfabeto" ou código genético). A sentença bíblica dizia: "Deixe que o homem domine sobre os peixes do mar, sobre as aves do céu e sobre todos os seres vivos que se movem na terra". O gene foi então introduzido em bactérias, que foram postas em placas de Petri. Nas exposições em galerias, as placas foram postas sob uma caixa de luz ultravioleta, controlada por participantes remotos na internet. Ao acionar a luz UV, participantes virtuais causavam mutação do código genético e assim mudavam o texto contido no corpo das bactérias. Após a exposição, o gene foi lido de volta para o inglês e o texto mutante publicado on-line na seção em inglês do site de Kac. (GONÇALVES, 2009, p. 106).

Este outro exemplo envolve conceitos de banco de dados e algoritmos, utilizando a coleta de informações para a construção de um organismo vivo, entituladoPocketsfullof memories (2001), do artista 
húngaro, também radicado nos Estados Unidos George Legrady, que busca trabalhar o fluxo de informação de sistemas complexos autoorganizativos como nova materiologia na arte.

Segundo o artista, Pockets é uma instalação interativa que trata da "criação e processamento de dados como prática cultural". A obra consiste na visualização e projeção do resultado de operações algorítmicas que estocam e processam dados coletados dos espectadores da exposição. [...] Curiosamente, o artista parece mostrar como a informação pode ser estocada, calculada e representada visualmente como uma espécie de mapa de cruzamento de memória coletiva sem, contudo, perder a dimensão individual das escolhas que formam seu conjunto. Mesmo transformadas em números, essas estatísticas parecem "vivas", apesar de serem produzidas a partir de determinados parâmetros. [...] É que, se por um lado, estes criam condições para as interações e seu ordenamento, por outro, eles não controlam seu acontecimento. [...] O que parece ser um procedimento que tudo tornaria previsível mostra exatamente a dinâmica imprevisível das interações mesmo sob determinadas condições. Ou seja, não é o sistema que torna os acontecimentos "previsíveis", são as interações que ao gerarem certas regularidades são passíveis de serem mostradas de uma determinada forma pelo sistema. Curiosamente, o que demostra o artista é que a performance dos algoritmos parece encarnar a instrumentalidade da técnica, que, no caso, é utilizada para capturar um "pedaço" de fluxo informacional e transformá-lo em imagem em tempo real. Não por acaso esse é o sistema utilizado por empresas como, por exemplo, Google, ou Amazon, que vão se utilizar dessa possibilidade de captura para organizar parâmetros e aplica-los segundo interesses mercadológicos. (GONÇALVES, 2009, p. 107).

Essa eterna dualidade entre o indivíduo e o coletivo, sobretudo no mundo das artes, encontra seu correspondente hoje, como a oposição entre a Rede e o Ser. Mesmo com as novas tecnologias da informação que permitem que o artista esteja mais conectado, este permanece ainda isolado, numa relação conturbada, como nos lembraCastells.

Nessa condição de esquizofrenia estrutural entre a função e o significado, os padrões de comunicação social ficam sob tensão crescente. E quando a comunicação se rompe, quando já não existe comunicação nem mesmo de forma conflituosa [...] surge uma alienação entre os grupos sociais e indivíduos que passam a considerar o outro um estranho, uma ameaça. (CASTELLS, 1999, p.41). 
Ou seja, tanto Legrady quanto Castells abordam questões da identidade do indivíduo num mundo dominado por essas interações tecnológicas entre o ser humano e o mundo informacional, apontando essas inquietações diante de um mundoonde os algoritmos, através da coleta de dados de pequenos hábitos, vão traçando perfis, onde há muitas vezes a perda dessa mesma identidade, em prol da massificação que visa atender a interesses mercadológicos.

\section{A rede e o ser artístico}

E como está o artista nesse sistema marchand-crítico?

Da mesma forma esquizofrênica, descrita anteriormente, o jovem artista se divide entre um regime de consumo linear, resquício do pensamento da arte moderna, e no regime circular baseado na comunicação. No primeiro regime, o valor da obra de arte se dá de forma autônoma, em si mesma, enquanto objeto mercadológico; o artista se torna uma figura marginal, submetido às flutuações do mercado - devidas em boa parte à concorrência, ao número crescente de artistas - e se coloca na dependência de marchands e críticos...

É o meio de manter intacta a fonte da produção, o criador, independente do mercado e, portanto, livre de qualquer suspeita de comercialização, para que sua credibilidade junto ao público permaneça inabalável. Voluntária ou não, a exibição do artista como anti, fora ou além das regras do mercado de consumo é tida como certa. Tática vitoriosa uma vez que, se já não se trata mais do estudante pobre em seu casebre, que frequenta tabernas com os amigos e arruína sua saúde e família - imagem herdada do século XIX romântico - nem por isso a imagem que o público faz do artista é muito diferente dessa historieta. Na verdade, esse público recusa a ideia de qualquer enriquecimento do artista, apegando-se à arte desinteressada, à criação "livre", oriunda do sofrimento, pronto a se tornar cego aos lucros reais e acusando sobretudo os intermediários de explorar o produtor, o artista. Vincent Van Gogh, o maldito, o exilado, da sociedade, estabelece o paradigma, obtendo todas as aprovações. (CAUQUELIN, 2005, p.48).

No regime circular baseado na comunicação, o valor da obra de arte já não está tão ligado ao objeto e sim à mensagem; existe uma rede de comunicação que adota outros valores para a obra de arte, de certa forma dificultando seu consumo, principalmente pelo público geral, aqueles que estão fora do circuito, que, por não entenderem mais as regras do jogo, acabam se afastando.

Portanto é importante notar o surgimento de uma forma de polarização entre o que poderia se denominar uma atitude burguesa de 
mecenato, ligada a uma questão mercadológica; e certo tipo de ativismo artístico, ligado a uma série de atitudes contestatórias (happenings, performances, etc.) e outras formas de arte engajada, que acabam sendo também uma forma de inserir-se no mercado da arte contemporânea. Tem-se daí as diferentes atitudes diante da tecnologia da informação, seja como forma de divulgação, negociação de obras de arte, para os partidários da arte no regime da estética e do consumo; seja para postar ideais artístico-políticos, usando a rede num processo de ativismo, para os partidários da arte no regime da comunicação, o que hoje acaba se tornando uma arte tecnológica, que, em geral, domina os grandes salões e é bastante dependente dos meios de comunicação, onde a internet, sobretudo as redes sociais, exercem um papel fundamental: propagação da imagem e dos ideais de determinado artista ou grupo artístico. Em ambos os casos, há ainda a presença das galerias como forma de dar escoamento a essa produção, de forma que o mercado das artes se comporta também de forma esquizofrênica - ao mesmo tempo em que incentiva o jovem artista a apurar sua habilidade técnica na pintura e o elogia, continua premiando a vídeo-arte e outras artes tecnológicas nos grandes salões.

\section{A relação do artista brasileiro com a internet: survey}

Foi realizada pesquisa de campo sobre o impacto que a internet pode ter trazido ao processo de interação entre artistas e o sistema de arte, seja na formação de rede de relacionamentos, rede de colaboração, como fonte de informações, como forma de articulação entre os artistas ou destes com agentes intermediários, objetivando sua inserção no circuito de consumo de obras de arte, considerando-se o modelo tripartite: produção, distribuição e consumo.

Através do surveyforam analisadas questões como frequência de uso, grau de habilidade, impactos, benefícios; detalhando-se, assim, a relação dos artistas com a internet em geral e com as redes sociais em particular. Foram entrevistados artistas e pessoas ligadas à arte, como pesquisadores, críticos, blogueiros. O questionário foi enviado por e-mail, e através de diversas redes sociais, como Google+, Linkedin, Facebook, Twiter. Mas foi através do Facebook, que se obteve maior retorno. Foram recolhidos 27 questionários respondidos, por pessoas de todo o Brasil.

Dentre os respondentes encontram-se pessoas ligadas basicamente à produção e a distribuição, demonstrando a evidente dificuldade de conhecer o grande consumidor de arte: o colecionista. Da categoria dos produtores de arte, encontramos estudantes ainda inexperientes; jovens artistas recém-formados que já possuem representação em galeria, sendo que um destes é professor universitário; experientes cineastas com currículos de premiações e participações em festivais de cinema; um ilustrador científico, representando a arte enquanto ofício; e também pesquisadores e leigos. 
A formação desses profissionais varia entre graduandos e bacharéis em artes visuais, especialistas e mestres em artes e áreas afins, como comunicação social, comunicação visual, história e cultura, ilustração científica, design de jogos digitais, design de interação, ensino de arte. Temos também a presença de pessoas sem formação artística oficial, autodidatas, um arquiteto, e uma pessoa formada em desenho industrial. Os artistas atuam, falando de forma geral, como pintores, gravadores, pesquisadores, participantes de grupos de ação coletiva, cineastas, designers, estilistas, ilustradores, ilustradores científicos. Grande parte é de Minas Gerais, e alguns representam outros estados como Rio de Janeiro, São Paulo, Bahia, Paraná. Além destes, há ainda um profissional ligado ao Museu Histórico do Rio de Janeiro, representando a área de museologia; um blogueiro, que poderia representar os críticos; e um galerista, este representando a categoria dos intermediários.

\section{Apresentação e análise dos resultados}

Dos benefícios buscados nas redes sociais pelos artistas, os que tiveram maior grau de avaliação,forambuscar e manter contatos profissionais e manter-se informados sobre o meio das artes - sendo que $64 \%$ dos entrevistados deram nota máxima a estes quesitos. Em contrapartida, os níveis de satisfação para estes quesitos caíram respectivamente para $39 \%$ e $25 \%$.

Tabela 1 - Nível de interesse e satisfação em relação ao uso das redes sociais

\begin{tabular}{|c|c|c|c|c|c|c|c|c|c|c|}
\hline & \multicolumn{5}{|c|}{ Nível de Interesse } & \multicolumn{5}{|c|}{ Nível de Satisfação } \\
\hline & Alto & Médio & Baixo & Baixís. & Nenh. & Alto & Médio & Baixo & Baixís. & Nenh. \\
\hline Buscar e manter contatos pessoais & $39 \%$ & $25 \%$ & $29 \%$ & $7 \%$ & $0 \%$ & $50 \%$ & $29 \%$ & $18 \%$ & $4 \%$ & $0 \%$ \\
\hline Buscar e manter contatos profissionais & $64 \%$ & $21 \%$ & $11 \%$ & $4 \%$ & $0 \%$ & $39 \%$ & $21 \%$ & $29 \%$ & $7 \%$ & $4 \%$ \\
\hline Participar de fóruns de discussão sobre arte & $21 \%$ & $21 \%$ & $29 \%$ & $18 \%$ & $11 \%$ & $7 \%$ & $25 \%$ & $43 \%$ & $14 \%$ & $11 \%$ \\
\hline Divulgar atividades relacionadas à arte & $57 \%$ & $29 \%$ & $11 \%$ & $0 \%$ & $4 \%$ & $39 \%$ & $36 \%$ & $18 \%$ & $4 \%$ & $4 \%$ \\
\hline Ter informação em tempo real dos meus contatos & $46 \%$ & $21 \%$ & $11 \%$ & $18 \%$ & $4 \%$ & $39 \%$ & $43 \%$ & $7 \%$ & $4 \%$ & $7 \%$ \\
\hline Distração momentânea (passatempo) & $14 \%$ & $11 \%$ & $18 \%$ & $29 \%$ & $29 \%$ & $29 \%$ & $11 \%$ & $11 \%$ & $25 \%$ & $25 \%$ \\
\hline Entretenimento/lazer & $14 \%$ & $11 \%$ & $32 \%$ & $18 \%$ & $25 \%$ & $29 \%$ & $14 \%$ & $11 \%$ & $32 \%$ & $14 \%$ \\
\hline Encontrar eventos artísticos online e no mundo real & $50 \%$ & $36 \%$ & $11 \%$ & $0 \%$ & $4 \%$ & $36 \%$ & $32 \%$ & $21 \%$ & $7 \%$ & $4 \%$ \\
\hline Comprar obras de arte em leilões virtuais & $7 \%$ & $4 \%$ & $7 \%$ & $21 \%$ & $61 \%$ & $0 \%$ & $7 \%$ & $11 \%$ & $18 \%$ & $64 \%$ \\
\hline Negociar obras de arte & $25 \%$ & $7 \%$ & $11 \%$ & $14 \%$ & $43 \%$ & $7 \%$ & $0 \%$ & $21 \%$ & $18 \%$ & $54 \%$ \\
\hline Divulgar atividades pessoais & $36 \%$ & $25 \%$ & $7 \%$ & $21 \%$ & $11 \%$ & $32 \%$ & $14 \%$ & $21 \%$ & $14 \%$ & $18 \%$ \\
\hline Obter informações sobre editais, salões, prêmios, etc. & $54 \%$ & $21 \%$ & $14 \%$ & $11 \%$ & $0 \%$ & $18 \%$ & $21 \%$ & $32 \%$ & $25 \%$ & $4 \%$ \\
\hline Manter-se informado sobre o meio das artes & $64 \%$ & $21 \%$ & $11 \%$ & $0 \%$ & $4 \%$ & $25 \%$ & $32 \%$ & $39 \%$ & $4 \%$ & $0 \%$ \\
\hline Visitar museus virtuais & $29 \%$ & $7 \%$ & $25 \%$ & $25 \%$ & $14 \%$ & $4 \%$ & $18 \%$ & $18 \%$ & $29 \%$ & $32 \%$ \\
\hline Outros & $14 \%$ & $14 \%$ & $14 \%$ & $18 \%$ & $39 \%$ & $7 \%$ & $4 \%$ & $14 \%$ & $21 \%$ & $54 \%$ \\
\hline
\end{tabular}

Fonte: Dados da pesquisa. 
Outra interessante comparação mostra que a maioria dos artistas está interessada em manter contatos profissionais, em detrimento de meros contatos pessoais. 64\% dos entrevistados acusaram um alto nível de interesse para este quesito contra $39 \%$ do outro. No entanto, ao perguntar o nível de satisfação ao atendimento destes mesmos quesitos, a situação se inverte, sendo que $50 \%$ dos entrevistados demonstraram estarem mais satisfeitos com o uso das redes sociais para manter contatos pessoais, contra 39\% para contatos profissionais.

Tabela 2 - Levantamento dos cadastros dos artistas nas redes e mídias sociais

\begin{tabular}{lcc}
\hline & Cadastro nas ferramentas/mídias/redes sociais da internet & \\
\hline Facebook & 28 & $100 \%$ \\
E-mail & 26 & $93 \%$ \\
Youtube & 18 & $64 \%$ \\
Linkedin & 15 & $54 \%$ \\
Google+ & 15 & $54 \%$ \\
\hline Blogger/Blogspot & 14 & $50 \%$ \\
Skype/ Vídeo Chats & 12 & $43 \%$ \\
\hline Orkut & 11 & $39 \%$ \\
Twitter & 11 & $39 \%$ \\
Flickr & 10 & $36 \%$ \\
Msn/Chats & 10 & $36 \%$ \\
\hline Boletins/Feeds de Notícias & 8 & $29 \%$ \\
Myspace & 4 & $14 \%$ \\
\hline Other & $14 \%$ \\
Gerenciadores de conteúdo. (WordPress/Joomla/etc.) & $14 \%$ \\
\hline Instagram & 4 & $11 \%$ \\
\hline Fonte: Dados da pesquisa. & $11 \%$ \\
\hline
\end{tabular}

Fonte: Dados da pesquisa.

Foi utilizada uma escala de 0 a 4, para cada quesito, o que pode ser traduzido como nível de interesse, ou no segundo caso, como nível de satisfação. O resumo completo pode ser visto na tabela 1 . O que se pode concluir da análise da tabela interesse $x$ satisfação, é que o nível de satisfação dos usuários artistas tende a cair quando comparado ao nível de interesse em determinado quesito, exceto nos itens contatos pessoais, distração momentânea, entretenimento/lazer, nos quais o nível de satisfação é maior que o nível de interesse. Por exemplo, 14\% dos entrevistados tem um alto nível de interesse em buscar entretenimento nas redes sociais, sendo que $29 \%$ destes mesmos entrevistados acusaram um alto nível de satisfação neste quesito. 
Tabela 3 - Dispositivos usados para o acesso à internet

\begin{tabular}{rrrrrr}
\hline \multicolumn{7}{c}{ De onde você acessa a internet com maior frequência? } \\
\hline & Alto & Normal & Médio & Baixo & Baixíssimo \\
Computador & $96 \%$ & $4 \%$ & $0 \%$ & $0 \%$ & $0 \%$ \\
Celular & $7 \%$ & $0 \%$ & $7 \%$ & $7 \%$ & $79 \%$ \\
Tablet & $0 \%$ & $14 \%$ & $0 \%$ & $0 \%$ & $86 \%$ \\
\hline
\end{tabular}

Fonte: Dados da pesquisa.

Outros pontos importantes são comprar obras de arte em leilões virtuais, e negociar obras de arte, onde $61 \%$ e $43 \%$, respectivamente, dos entrevistados têm nenhum interesse nesse quesito, e $64 \%$ e $54 \%$ tem nível de satisfação zero. No entanto, $25 \%$ ainda buscam com alto nível de interesse negociar obras de arte, o que pode ser um número significativo, considerando as dificuldades do mercado de arte, e a incipiência das novas tecnologias da informação com este fim específico. Porém o nível de satisfação oscila entre baixo e baixíssimo.

Tabela 4 - Nível de frequência das ferramentas/mídias sociais

\begin{tabular}{lrrrrr}
\hline \multicolumn{1}{c}{$\begin{array}{c}\text { Nível de frequência ferramentas/mídias/redes sociais da } \\
\text { Internet }\end{array}$} & Alto & Regular & Médio & Baixo & Baixissimo \\
\hline E-mail & $93 \%$ & $7 \%$ & $0 \%$ & $0 \%$ & $0 \%$ \\
\hline Facebook & $75 \%$ & $11 \%$ & $11 \%$ & $4 \%$ & $0 \%$ \\
\hline Portais de Notícias & $36 \%$ & $18 \%$ & $25 \%$ & $11 \%$ & $11 \%$ \\
\hline Youtube & $29 \%$ & $18 \%$ & $25 \%$ & $14 \%$ & $14 \%$ \\
\hline Google+ & $14 \%$ & $14 \%$ & $7 \%$ & $21 \%$ & $43 \%$ \\
\hline Skype/Video Chats & $7 \%$ & $7 \%$ & $11 \%$ & $25 \%$ & $50 \%$ \\
\hline Chats & $7 \%$ & $0 \%$ & $4 \%$ & $4 \%$ & $82 \%$ \\
\hline Boletins (feeds) de notícias por e-mail & $7 \%$ & $11 \%$ & $25 \%$ & $25 \%$ & $32 \%$ \\
\hline Twitter & $4 \%$ & $7 \%$ & $7 \%$ & $25 \%$ & $57 \%$ \\
\hline Linkedin & $4 \%$ & $14 \%$ & $7 \%$ & $21 \%$ & $54 \%$ \\
\hline Gerenciadores de Conteúdo. (WordPress/Joomla/Etc.) & $4 \%$ & $0 \%$ & $11 \%$ & $11 \%$ & $75 \%$ \\
\hline Flickr & $4 \%$ & $7 \%$ & $11 \%$ & $21 \%$ & $57 \%$ \\
\hline Outros & $0 \%$ & $4 \%$ & $7 \%$ & $4 \%$ & $82 \%$ \\
\hline Orkut & $0 \%$ & $0 \%$ & $4 \%$ & $14 \%$ & $82 \%$ \\
\hline Myspace & $0 \%$ & $0 \%$ & $0 \%$ & $7 \%$ & $93 \%$ \\
\hline Instagram & $0 \%$ & $0 \%$ & $0 \%$ & $7 \%$ & $93 \%$ \\
\hline Fonte: Dacos
\end{tabular}

Fonte: Dados da pesquisa.

Dentre os benefícios citados, os entrevistados apresentam maior nível de interesse para buscar e manter contatos pessoais e profissionais, divulgar atividades relacionadas à arte, ter informação em tempo real de seus contatos, encontrar eventos artísticos online e no mundo real, divulgar atividades pessoais, obter informações sobre oportunidades no mundo artístico e manterem-se informados sobre o circuito das artes; ou seja, maior interesse em atividades profissionais em relação ao meio 
artístico do que mero entretenimento ou lazer. Já no nível de satisfação essa maioria se desfaz, e acaba oscilando entre médio, baixo e baixíssimo em relação a alguns destes mesmos itens, como obter informações sobre oportunidades e manter-se informado sobre o meio artístico. Das ferramentas disponíveis na internet, a pesquisa mostra que o e-mail e o Facebook são as ferramentas com maior número de cadastros e maior nível de frequência. (Talvez possa surgir daí algum tipo de convergência). Foi mencionado também o Pinterest que não estava listado dentre os demais. Já não é nenhuma novidade, a queda do uso do Orkut, tendo $82 \%$ apontado nenhum uso desta ferramenta.

O uso de ferramentas avançadas, como os gerenciadores de conteúdo que permitem a criação de portais, também é pouco usado, apesar de $86 \%$ dos artistas entrevistados produzirem conteúdo pela internet. Deste conteúdo produzido, $84 \%$ são através das redes sociais, e $68 \%$ através de blogs, mostrando que a facilidade proporcionada por essas ferramentas, decorrentes do que se conhece como web 2.0, é interessante para os artistas produzirem seu próprio conteúdo, sem terem grandes conhecimentos sobre programação. Ainda temos $32 \%$ dos entrevistados produzindo conteúdo através de blogs, 16\% através de gerenciadores de conteúdo, como Joomla, Wordpress, etc., e $12 \%$ através de outros meios. Dos 28 entrevistados, 4 consideram seu conhecimento sobre internet regular, 14 o consideram médio, 8 o consideram bom, e 2, excelente. Apesar disso, ainda é possível produzirem conteúdo na internet.

A maioria dos artistas acessa a internet pelo computador, sendo pouco ainda, o uso do tablet ou de smartphones. A média de uso da internet para $57 \%$ dos artistas entrevistados é de duas a quatro horas por dia para, já a dedicação diária para as redes sociais, 46\% responderam de uma a duas horas por dia. Dos 28 entrevistados, 22 não tem representação em galeria contra 6 que são representados comercialmente por galerias.

Já nas questões abertas, quando perguntados sobre a presença da internet no processo de inserção no mercado de artes, quase todos os entrevistados avaliaram-na como positiva, com apenas algumas ressalvas, como a incipiência, falta de profissionalismo, a não influência de forma direta na inserção no mercado de arte, apesar de ser um importante meio de divulgação, enquanto outros acreditam serpossível montar-se um grupo e realizar-se uma exposição mantendo-se contato apenas pela internet.

Na segunda questão aberta, foi abordada a influência da internet no pensamento artístico, e novamente a grande maioria respondeu que percebe essa influência. A facilidade de acesso a informações nos influencia, influencia a cultura contemporânea como um todo, ampliando os horizontes profissionais - foi o que foi dito de forma geral.

A partir dos resultados, podemos tecer algumas conclusões sobre a forma como a internet e as redes sociais influenciam o pensamento artístico e o processo de inserção no mercado: 
a)ainternet pode facilitar a negociação de trabalhos artísticos;

b)ainternet $e$ as redes sociais podem influenciar a cultura contemporânea como um todo, afetando também o meio artístico;

c)ainternet, sobretudo as redes sociais propiciam divulgação e propagação imediata de conteúdo em vários formatos, intercâmbio de conhecimento e formação de opinião através de debates;

d)as propostas artísticas estão cada vez mais abrangentes, incorporando novos meios de comunicação, novas mídias, sendo a internet uma possibilidade em potencial expansão e exploração;

e)a circulação de informação sempre possibilita a mudança de atitude;

f)no entanto, embora favoreça a circulação de informações, há grande propagação de conteúdos rasos na rede, e pouco espaço para debates profundos, propiciando a banalização do conteúdo e falta de capacidade crítica.

g)em campos específicos da arte, sempre há a possibilidade de formação de grupos com interesses em comum, para trocas de informações;

h)a facilidade de acesso, trazida pela internet, a conteúdos outrora considerados raríssimos, como a produção dos grandes centros como Estados Unidos, Alemanha, Japão, possibilita a evolução da linguagem estética e cultural entre os jovens artistas, facilitando o surgimento de artistas com uma produção diferenciada;

i)a internet é também uma importante fonte de informação sobre eventos de arte.

\section{Conclusão}

Como resultado deste trabalho, conclui-se que tanto para o artista local quanto para o artista que consegue reconhecimento nos salões internacionais, o uso das redes sociais como forma de divulgação e interação com o meio artístico é hoje fundamental. Os avanços das ferramentas e mídias da internet permite que a produção de conteúdo seja feita de forma cada vez mais fácil e intuitiva, sendo que não é necessário possuir grandes conhecimentos de informática para produzir um site ou um blog. Além desta facilidade, outro interessante aspecto que as redes sociais apresentam é a maior facilidade e velocidade de propagação do conteúdo e a interação direta com o público. 
Os resultados nos permitiram perceber o interesse sobre as redes sociais e sobre a aquisição de conhecimento sobre o uso das redes e a organização da informação por parte de artistas, estudiosos e instituições. Entender como a internet e as redes sociais interagem com o campo das artes visuais, significa entender conceitos de redes, banco de dados, coleta, organização e análise da informação.

É interessante perceber como os conceitos de redes, os bancos de dados, os sistemas, se comportam de maneira orgânica, viva; que a tecnologia atua no sentido de facilitar a construção de relacionamentos e intercâmbio interpessoal; e como através da coleta de dados brutos de diversos eventos de arte espalhados na rede de forma aleatória, seu armazenamento e posterior análise, pode-se construir valiosas informações.

De forma geral, a inserção no mercado de artes apresenta como principal problema certos tabus existentes no meio artístico em abordar a questão mercadológica abertamente. As redes de informação foram vistas, pela maioria dos entrevistados, como um caminho para ultrapassar esse tabu.

Essa pesquisa permitiu aproximar dois campos do conhecimento, Arte e Informação, e, mais especificamente, aprofundar o entendimento sobre o impacto da internet e das redes sociais nos circuitos artísticos, e na interação de jovens artistas com as tecnologias da informação, internet e redes sociais no processo de sua inserção.

Como questionamentos abertos, a serem abordados no futuro, fica um grande leque de possibilidades: o crowdsourcinge a criação artística; a arte como ativismo virtual (hacktivismo); arte, genética e informação (ativismo bio-político); Web Art; cinema e sociedade da informação; a nova televisão, através de aparelhos conectados, e a mudança na cultura de massa, entre outros.

Ou seja, as diferentes facetas do impacto das redes de informação na cultura, em particular, na arte.

\section{Referências}

AGUIAR, S. Redes sociais e tecnologias digitais de informação e comunicação. [Relatório de Pesquisa].Rio de Janeiro: Nupef, 2006. Disponível em: <http://www.nupef.org.br/sites/default/files/rel_nupef_redes_2006.pdf>. Acesso em: 13 maio 2014.

BUENO, M. L. Do moderno ao contemporâneo: uma perspectiva sociológica da modernidade nas artes plásticas. Revista de Ciências Sociais, Ceará, v.41, n.1, p. 27-47, 2010. Disponível em: <http://www.rcs.ufc.br/edicoes/v41n1/rcs_v41n1a3.pdf.> Acesso em: 25 abr. 2014.

CANETTI, P. K. Análise e visualização de eventos de arte como rede social. In: SIMPÓSIO INTERNACIONAL FUTUROS POSSÍVEIS NA FAU-USP, 2012, São Paulo. Anais... São Paulo:Canal Contemporâneo, 2012. Disponível 
em: <http://prezi.com/kugvptgeqtvn/analise-e-visualizacao-de-eventosde-arte-como-rede-social/\#_=_>. Acesso em: 26 dez 2012.

CASTELLS, M. A sociedade em rede. São Paulo: Paz e Terra, 1999.

CAUQUELIN, A. Arte contemporânea, uma introdução. São Paulo: Martins Fontes, 2005.

GENESIS. 1999. Disponível em: <http://www.ekac.org/geninfo.html>. Acesso em: 13 de maio de 2014.

GONÇALVES, F. do N. Tecnologia e cultura: usos artísticos da tecnologia como prática de comunicação e laboratório de experimentação social. Revista FAMECOS, PortoAlegre,n. 38, p.100-110, abr. 2009. Disponível em:

<http://revistaseletronicas.pucrs.br/ojs/index.php/revistafamecos/article/ view/5307/3877> . Acesso em: 25 abr. 2014. 